\title{
An Evaluation of the Calorific Values of the Branches and Stems of 11 Tropical Trees
}

\author{
Jude I. Duruaku*, Vincent I. E. Ajiwe, Nkechi H. Okoye, Rosemary U. Arinze \\ Department of Pure and Industrial Chemistry, Nnamdi Azikwe University Awka, Awka, Nigeria \\ Email: *duruakucssp@yahoo.com,vaj_04@yahoo.com, helenhills2001@yahoo.com, arimay2002@yahoo.com
}

Received 4 April 2016; accepted 31 May 2016; published 3 June 2016

Copyright (C) 2016 by authors and Scientific Research Publishing Inc.

This work is licensed under the Creative Commons Attribution International License (CC BY).

http://creativecommons.org/licenses/by/4.0/

(c) (i) Open Access

\section{Abstract}

This work investigated and quantified the calorific values of the main branches and trunks of eleven (11) tropical trees in correlation with their chemical composition in order to assess their suitability for use as credible sources of wood fuel. The determination of the carbon, hydrogen, nitrogen, oxygen and sulphur (CHNOS) content of the samples was done using an organic elemental analyser, while an oxygen bomb calorimeter was used to experimentally determine their corresponding gross heat values. The experimental gross heat values for the branches examined ranged from 18,703.37 kJ/kg in Lophira lanceolata to 21,350.35 kJ/ $\mathrm{kg}$ in Afzelia africana while that of the trunks ranged from 19,747.74 kJ/kg in Tectonia grandis to $22,408.68 \mathrm{~kJ} / \mathrm{kg}$ in Prosopis africana. These values were within and about the expected ranges observed for tropical trees and may be considered adequate for wood fuel. The general trend in both branches and trunks was that the higher the carbon content, the higher the gross heat value of sample. The absence of sulphur in almost all the samples except, Prosopis africana, $(0.055 \%)$ was indicative of the fact that the negative environmental impact with respect to harmful emissions of oxides of sulphur is practically non-existent with respect to these species. In the light of the aforementioned variables, the main branches of Afzelia africana $(21,350.35 \mathrm{~kJ} / \mathrm{kg})$, Nauclea diderrichii $(21,157.30 \mathrm{~kJ} / \mathrm{kg})$ and Tectonia grandis $(20,257.13 \mathrm{~kJ} / \mathrm{kg})$ could be used as credible sources of firewood and charcoal production. With respect to the trunks, the timbers in order of preference would ideally be Prosopis africana $(22,408.68 \mathrm{~kJ} / \mathrm{kg})$, Nauclea diderichii $(21,436.42 \mathrm{~kJ} / \mathrm{kg})$ and Brachstigia eurychoma $(20,924.7$ $\mathrm{kJ} / \mathrm{kg}$ ).

\section{Keywords}

Calorific Value, Elemental Composition, Gross Heat Value, Bulk Density, Ash Content

${ }^{*}$ Corresponding author.

How to cite this paper: Duruaku, J.I., Ajiwe, V.I.E., Okoye, N.H. and Arinze, R.U. (2016) An Evaluation of the Calorific Values of the Branches and Stems of 11 Tropical Trees. Journal of Sustainable Bioenergy Systems, 6, 44-54.

http://dx.doi.org/10.4236/jsbs.2016.62005 


\section{Introduction}

In the background of the alarms being raised by various interest groups and stakeholders over the continued degradation of the environment, no thanks to the uncontrolled use of fossil fuels on the one hand and the cost of petroleum on the other, there has been a growing trend in the search for alternative sources of energy which are considered to be cleaner and more environmentally friendly. Wood fuel (firewood and charcoal) is once again being appreciated [1]. Wood has the flexibility of being modified into various forms that are convenient to use like charcoal, liquid fuels (methanol and ethanol) and producer gas (carbon monoxide and nitrogen) [2]. They also reported that Charcoal is mainly made of carbon and is obtained from the destructive distillation of wood with a relatively high-energy value of $28.9 \mathrm{GJ} /$ tonne. In terms of potential energy per kilogram therefore, this value is definitely higher than that for raw wood [3]. Charcoal has a steady burning and produces less smoke and less unhealthy vapours compared to raw wood [4]. Other advantages of using charcoal as a bio-fuel include its negligible sulphur content (unlike other fossil fuels), its higher heating value (heat of combustion), lower water content when compared with ordinary wood, and a relative stability in the presence of microbial agents [5].

Since it may be argued that the resulting properties of charcoal are a function of the chemical properties of the biomass source, it becomes therefore expedient to examine certain parameters that determine the final properties of charcoal with respect to different types of woods available in our local environment so as to make the best choice of species for its production. One of such parameters is the calorific value of the biomass in question [6]. For example, if the thesis that the heating value of the charcoal is dependent on the chemical structure of the parent wood is accepted [2], then we may seek to determine experimentally the higher heating value which we suppose is a function of wood composition in order to approximate the energy content of a particular species of wood. The present work investigated the calorific value of 11 tropical trees in correlation with their chemical composition.

\section{Materials and Methods}

\subsection{Sample Collection}

Samples of the main branches and trunks of 11tropical timbers were obtained from various forests located in Enugu State with the assistance of a well-trained government forestry official during the dry season. The selected timbers were: Erythrophleum suaveolens, Dialium guinensis, Pentaclethra macrophylla, Lophira lanceolata, Prosopis africana, Nauclea diderrichii, Brachistigia eurycoma, Afzelia africana, Albizie ferruginea, Tectonia grandis, and Morinda lucida. They were milled and ground and passed through a 40 mesh sieve (approximately 0.017inches in diameter) in preparation for the tests.

\subsection{Experimental Procedures}

\subsubsection{Determination of Carbon, Hydrogen, Nitrogen and Sulphur Content of Samples [7]}

The samples of air dried wood were crushed and ground into fine particles. With the aid of a spatula, they were weighed ( $3 \mathrm{mg}$ per sample) with a microbalance (Toledo MX5) in Tin capsules, placed inside the Thermo Scientific MAS 200R autosampler at a preset time (0 - $150 \mathrm{~s})$, and then dropped into an oxidation/reduction reactor (combustion reactor) kept at a temperature of $950^{\circ} \mathrm{C}$. The exact amount of oxygen required for optimum combustion of the sample $(250 \mathrm{ml} / \mathrm{min})$ was delivered into the combustion reactor at a precise time $(0-150 \mathrm{~s})$. After combustion, the resultant gases were carried by a helium flow to a layer filled with copper, then swept through a Gas Chromatograph Column where the gases were separated, and finally detected by a Thermal Conductivity Detector (TCD). The estimated total run time for this process was 600 seconds (10 minutes). For sulphur determination, the gases produced by combustion were carried by a helium flow to a layer filled with copper, then swept through a water trap, a short gas chromatograph column. The concentration of sulphur present was measured by a flame photometric detector (FPD).

\subsubsection{Determination of Oxygen Content of Sample [7]}

The target samples (2 mg per sample) were weighed and introduced into the pyrolysis chamber via the MAS 200R autosampler. The reactor contained a "nickel coated carbon" catalyst maintained at $1060^{\circ} \mathrm{C}$, specifically developed for this application. The oxygen present in the sample combined with the carbon, to form carbon 
monoxide which was then chromatographically separated from other products and detected by TCD detector. The total run time was 300 seconds (5 minutes). A complete report was automatically generated by a dedicated Eager 300 data handling software and displayed at the end of the analysis.

\subsubsection{Determination of the Gross Heating Values of Samples Using Parr Oxygen Bomb Calorimeter, Model 134}

The Gross Heat Values were determined by ASTM Standards (Standard Test Method for Gross Calorific Value of Coal and Coke: D 5865-98a [8].

\subsubsection{Determination of Ash Content [9] [10]}

Dry samples ( $2 \mathrm{~g}$ ) were placed in a pre-weighed porcelain crucible and transferred into a preheated muffle furnace set at a temperature of $600^{\circ} \mathrm{C}$ for 1 hour after which the crucible and its content were transferred to a desiccator and allowed to cool. The crucible and its content were reweighed and the new weight noted. The percentage ash content was calculated with the formula:

$$
\mathrm{A}_{\mathrm{c}}(\%)=\left(\mathrm{W}_{\mathrm{a}} / \mathrm{W}_{\mathrm{o}}\right) \times 100
$$

where $A_{c}$ is the ash content in percentage; $W_{a}$ is the weight of ash after cooling and $W_{0}$ is the original weight of dry sorbent.

\subsubsection{Determination of the Bulk Density [11]}

A portion (5 g) was accurately weighed and poured into a $100 \mathrm{ml}$ graduated cylinder. The cylinder was stoppered and the bulk volume $\mathrm{V}_{\mathrm{o}}$ was recorded. The bulk density was determined as:

$$
\mathrm{D}_{\text {bulk }}=\mathrm{W} / \mathrm{V}_{\mathrm{o}}
$$

where $\mathrm{W}$ = weight of sample.

\section{Results and Discussion}

\subsection{Gross Heat Value/Carbon Content}

The carbon content of branch samples (Table 1) ranged from the highest value in Afzelia africana (48.210\%) to the lowest in Prosopis africana (42.804\%). With respect to the trunks (Table 2), it ranged from Prosopis africana (49.813\%) to Morinda lucida (41.847\%). Results showed that carbon content contributed positively to the experimental gross heat value (GHVe). There was a significant difference in the \% content of the elements irrespective of the tree parts $[\mathrm{F}$ calculated $=7.532 \mathrm{E} 3$ and is significant at $0.000(\mathrm{P} \leq 0.05)$ for the branches; $\mathrm{F}=$ $2.959 \mathrm{E} 3$ was significant at 0.000 for the trunks]. Using Scheffe's test, the significance was found to be in the direction of the element $\mathrm{C}$ in the trees. The positive correlation with the gross heat value with respect to the \% $\mathrm{C}$

Table 1. Experimental results of the analysis of the main branches of 11 tropical timbers.

\begin{tabular}{cccccccccc}
\hline Botanic Name of Tree & $\mathbf{N \%}$ & $\mathbf{C} \%$ & $\mathbf{H} \%$ & $\mathbf{S} \%$ & $\mathbf{0 \%}$ & $\begin{array}{c}\text { GHVe } \\
\mathbf{( k J / k g})\end{array}$ & $\begin{array}{c}\text { \%Ash } \\
\text { Content }\end{array}$ & $\begin{array}{c}\text { B.D. } \\
\left(\mathbf{g} / \mathbf{c m}^{3}\right)\end{array}$ & $\mathbf{C O}_{2} \mathbf{E . F .}$ \\
\hline Lophira lanceolata & 0.324 & 46.399 & 6.026 & 0.000 & 42.410 & 18703.37 & 4.00 & 0.188 & 108.473 \\
Pentaclethra macrophylla & 0.350 & 46.398 & 6.128 & 0.000 & 42.503 & 18801.06 & 2.31 & 0.192 & 107.726 \\
Brachistigia eurycoma & 0.106 & 44.588 & 5.936 & 0.000 & 42.288 & 18924.34 & 4.66 & 0.217 & 109.209 \\
Prosopis africana & 0.525 & 42.804 & 5.877 & 0.055 & 43.298 & 18942.94 & 1.94 & 0.079 & 111.310 \\
Erythophleum suaveolens & 0.225 & 47.353 & 6.159 & 0.000 & 40.872 & 18945.27 & 1.94 & 0.284 & 105.534 \\
Dialium guinensis & 0.309 & 44.458 & 6.120 & 0.000 & 41.790 & 19426.75 & 2.94 & 0.139 & 106.930 \\
Albizie ferruginea & 0.284 & 45.355 & 6.026 & 0.000 & 43.068 & 19557.01 & 0.98 & 0.172 & 109.354 \\
Morinda lucida & 0.266 & 44.301 & 6.051 & 0.000 & 41.918 & 19622.14 & 3.00 & 0.108 & 107.696 \\
Tectonia grandis & 0.218 & 45.455 & 6.109 & 0.000 & 44.518 & 20257.13 & 2.94 & 0.105 & 110.639 \\
Nauclea diderichii & 0.421 & 46.519 & 6.223 & 0.000 & 40.608 & 21157.30 & 1.84 & 0.108 & 104.703 \\
Afzelia africana & 0.215 & 48.210 & 6.029 & 0.000 & 40.585 & 21350.35 & 2.50 & 0.238 & 106.240 \\
\hline
\end{tabular}


Table 2. Experimental results of the analysis of the trunks of 11 tropical timbers.

\begin{tabular}{|c|c|c|c|c|c|c|c|c|c|}
\hline Botanic Name of Tree & N\% & $\mathrm{C} \%$ & H\% & $\mathrm{S} \%$ & O\% & $\begin{array}{l}\text { GHVe } \\
(\mathbf{k J} / \mathbf{k g})\end{array}$ & $\begin{array}{c}\% \text { Ash } \\
\text { Content }\end{array}$ & $\begin{array}{l}\text { B. D. } \\
\left(\mathrm{g} / \mathrm{cm}^{3}\right)\end{array}$ & $\begin{array}{l}\mathrm{CO}_{2} \\
\text { E.F. }\end{array}$ \\
\hline Tectonia grandis & 0.125 & 47.245 & 6.253 & 0.000 & 35.661 & 19747.74 & 5.05 & 0.250 & 99.558 \\
\hline Morinda lucida & 0.319 & 41.847 & 5.913 & 0.000 & 42.905 & 19819.85 & 1.33 & 0.111 & 110.439 \\
\hline Pentaclethra macrophylla & 0.344 & 44.057 & 6.115 & 0.000 & 40.802 & 20059.42 & 2.00 & 0.161 & 105.782 \\
\hline Dialium guinensis & 0.252 & 44.552 & 6.250 & 0.000 & 41.038 & 20166.42 & 2.94 & 0.166 & 104.916 \\
\hline Lophira lanceolata & 0.272 & 46.838 & 6.210 & 0.000 & 43.025 & 20720.01 & 3.05 & 0.250 & 107.688 \\
\hline Afzelia africana & 0.256 & 45.829 & 6.227 & 0.000 & 40.067 & 20792.11 & 7.69 & 0.194 & 104.003 \\
\hline Albizie ferruginea & 0.627 & 43.746 & 6.286 & 0.000 & 41.754 & 20810.72 & 0.10 & 0.160 & 105.458 \\
\hline Erythophleum suaveolens & 0.252 & 47.520 & 6.246 & 0.000 & 40.900 & 20829.33 & 1.00 & 0.258 & 104.901 \\
\hline Brachistigia eurycoma & 0.305 & 45.392 & 6.104 & 0.000 & 41.927 & 20924.70 & 1.92 & 0.207 & 107.232 \\
\hline Nauclea diderichii & 0.455 & 47.915 & 6.364 & 0.000 & 38.763 & 21436.42 & 2.38 & 0.245 & 101.693 \\
\hline Prosopis africana & 0.318 & 49.813 & 6.003 & 0.000 & 39.385 & 22408.68 & 5.88 & 0.261 & 105.130 \\
\hline $\begin{array}{c}\text { Austria ONORM M7135 } \\
{[12]}\end{array}$ & $\leq 0.6$ & & & $\leq 0.08$ & & $\geq 18.0$ & & & \\
\hline $\begin{array}{c}\text { German DIN } \\
\text { 51731/DINplus [12] }\end{array}$ & $<0.3$ & & & $<0.08$ & & $17.5-19.5$ & & & \\
\hline
\end{tabular}

The results of the analysis of the main branches and trunks of eleven tropical trees are shown $\left(\right.$ Table 1 \& Table 2). B.D. = Bulk Density; CO $\mathbf{O}_{2}$ E.F. = Carbon dioxide emission factor; GHVe = Gross Heat Value (Experimental).

content of the trees for both branches and trunks is depicted in Figure 1 and Figure 2. This shows that the effect of the $\mathrm{C}$ content on the calorific value was stronger in the case of the trunks than in the branches. The trunks had correlation coefficient squared $\left(\mathrm{R}^{2}\right)$ factor of 0.483 , while the branches had a much weaker value $\left(\mathrm{R}^{2}=0.178\right)$. Afzelia africana $(21,350.35 \mathrm{~kJ} / \mathrm{kg})$ and Nauclea diderrichii $(21,157.30 \mathrm{~kJ} / \mathrm{kg}$ ) had carbon concentrations of 48.210\% and 46.519\% respectively with respect to their branches. However, Lophira lanceolata which had relatively high carbon content (46.399\%) unexpectedly had the lowest GHVe (18, $703.37 \mathrm{~kJ} / \mathrm{kg})$.

The same trend (increased energy as carbon content increases) was observed in the case of the trunks. Prosopis africana $(22,408.68 \mathrm{~kJ} / \mathrm{kg})$ and Nauclea diderichii $(21436.42 \mathrm{~kJ} / \mathrm{kg})$ had carbon concentrations of $49.813 \%$ and $47.915 \%$ respectively. However, Tectonia grandis which had a relatively high C content (47.245\%) had the lowest GHVe $(19,747.74 \mathrm{~kJ} / \mathrm{kg})$. These results show that carbon content alone is not the only contributing factor to the energy value. Other factors include the ash content [13] and extractives [14] [15]. The relatively high ash contents of the branch of Lophira lanceolata (4\%) and the trunk of Tectonia grandis (5.05\%) may have contributed to the lowering of their energy values. It has been observed that extractive contents raised the higher heating value of wood fuel [14]. These results however suggest that the effects of the ash content as a heat sink outweighed the corresponding effect of the extractives with respect to the trees in question.

\subsection{Gross Heat Value/Hydrogen Content}

Hydrogen content of branch tree sample (Table 1) ranged from the highest value in Nauclea diderrichii (6.223\%) to the lowest in Prosopis africana (5.877\%). With respect to the trunks (Table 2), it ranged from Nauclea diderrichii (6.364\%) to Morinda lucida (5.913\%). These values were well within the expected ranges for hydrogen content of biomass dry matter which is 5\% - 6\% [12]. The application of statistical tools (T-Test) to the results of the analysis with respect to the \% $\mathrm{H}$ content of the samples showed that the difference between the main branches and their respective main trunks was significant $(0.031 \leq 0.05)$. The hydrogen content of the trunk samples were generally more than their respective branch samples. It also showed a positive correlation with the gross heat value as shown in (Figure 3 and Figure 4) for both branches and trunks. It was noted that the effect of the $\mathrm{H}$ content on the calorific value was stronger in the case of the branches which had a higher correlation coefficient squared $\left(\mathrm{R}^{2}=0.132\right)$ than in the trunks $\left(\mathrm{R}^{2}=0.002\right)$. 


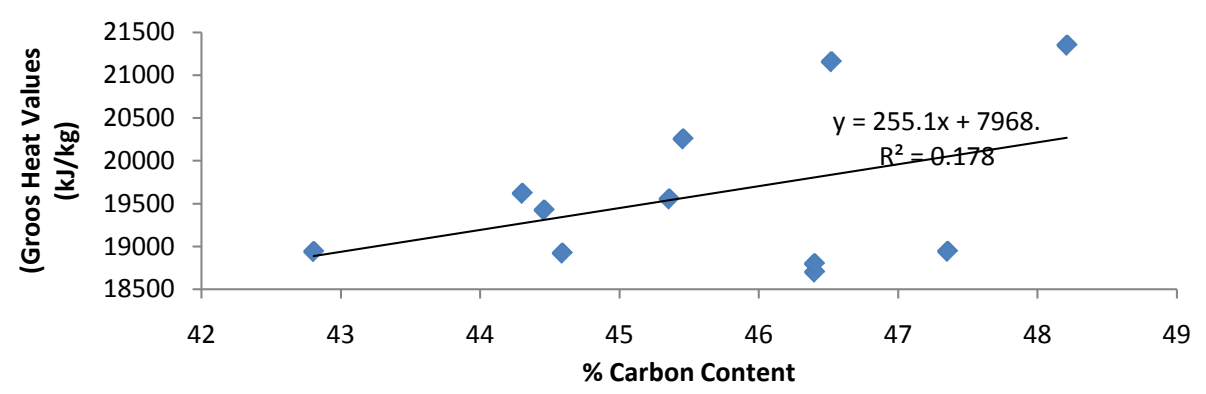

Figure 1. A Plot of experimental gross heat value versus \% carbon content of selected trees (branches).

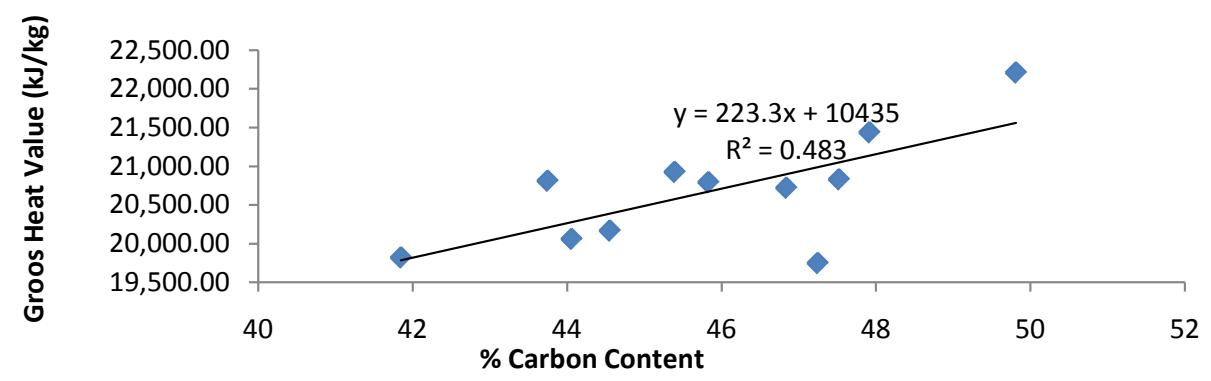

Figure 2. A Plot of experimental gross heat value versus \% carbon content of selected trees (trunks).

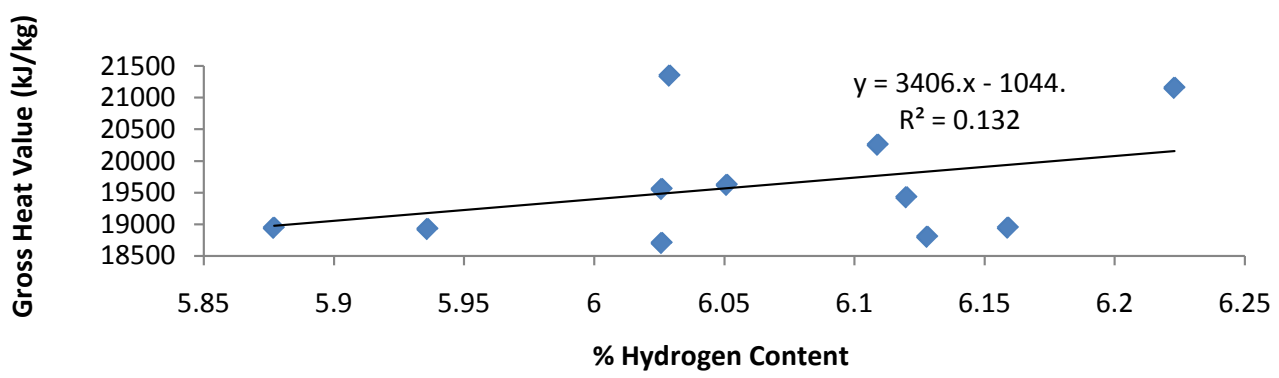

Figure 3. A Plot of experimental gross heat value versus \% hydrogen content of selected trees (branches).

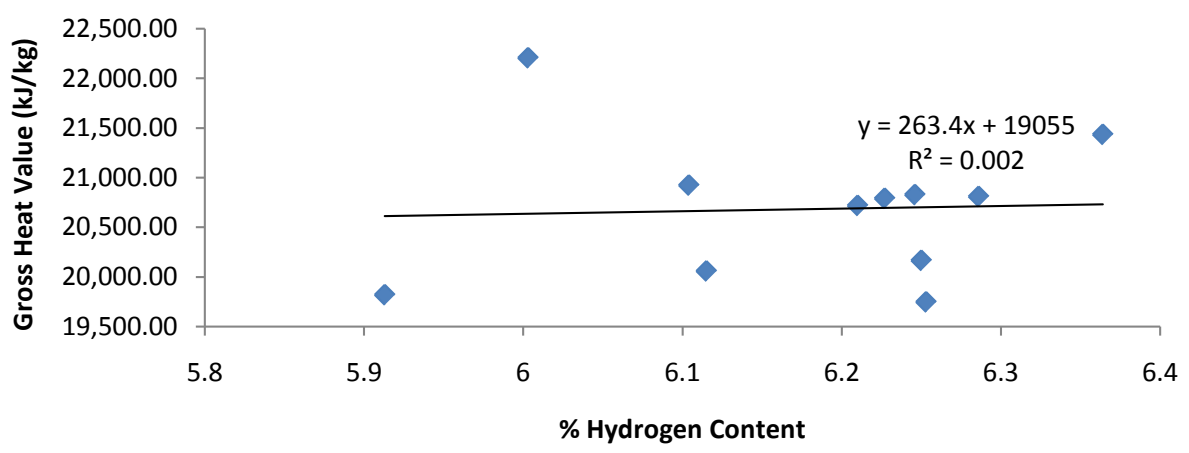

Figure 4. A Plot of experimental gross heat value versus \% hydrogen content of selected trees (trunks).

\subsection{Gross Heat Values/Oxygen Concentration}

The oxygen content of branch samples (Table 1) ranged from the highest value in Tectonia grandis (44.518\%) to the lowest in Afzelia africana (40.585\%). With respect to the trunks (Table 2), it ranged from Lophira lanceolata $(43.025 \%)$ to Tectonia grandis (35.661\%). The oxygen concentration correlated negatively (between species) 
with the gross heat value. The effect of the negative correlation of oxygen with the calorific value as shown (Figure 5 and Figure 6) was more pronounced in the branches $\left(\mathrm{R}^{2}=0.131\right)$ than in the trunks $\left(\mathrm{R}^{2}=0.001\right)$. Data analysis (T-test) showed that the difference between the main branches and their respective main trunks was significant $(0.04 \leq 0.05)$. It was noted that the oxygen content of the branch samples were generally more than that of the trunks (within species) except in the cases of Lophira lanceolata (main branch, $42.410 \%<$ main trunk, 43.025\%), Erythrophleum suaveolens (main branch, 40.872\% < main trunk, 40.900\% and Morinda lucida (main branch, 41.918\% < main trunk, 42.905\%), where there was a reversal of the trend. It was noted that the sample with the lowest oxygen concentration had the highest gross heat value. For example Afzelia africana with an oxygen concentration of $40.585 \%$ had an experimental gross heat value (GHVe) of 21,350.35 kJ/kg followed by Nauclea diderrichii with an oxygen concentration of $40.608 \%$ and a GHVe of $21157.30 \mathrm{~kJ} / \mathrm{kg}$. This is in line with the observation that the concentration of oxygen that negatively affected the higher heating value (HHV) was in the range of $40.60 \% \mathrm{wt}-45.2 \mathrm{wt} \%(\mathrm{db})$ for all species [16].

With the trunk samples, Prosopis africana which had the highest GHVe of 22,408.68 kJ/kg had an oxygen concentration of $39.385 \%$ while Nauclea diderrichii $(21,436.42 \mathrm{~kJ} / \mathrm{kg}$ ) had a value of $38.763 \%$. But this trend does not continue with regard to Tectonia grandis which had the lowest oxygen concentration of $35.661 \%$ and also the lowest GHVe of $19,747.74 \mathrm{~kJ} / \mathrm{kg}$ as well. This implied that oxygen concentration was not the only determinant factor in the GHVe of a species since the concentration levels of other elements like $\mathrm{C}$ and $\mathrm{H}$ as well as the ash content should be considered as well.

\subsection{Nitrogen Content}

This is a good indicator of the concentration of nitrogen-based toxic components that can be generated during combustion [12]. It was observed that nitrogen content ranged from Prosopis africana (0.525\%) to Brachistigia eurycoma $(0.106 \%)$ for the branch samples (Table 1$)$. For the trunk samples (Table 2), the range was from Albizie ferruginea $(0.627 \%)$ to Tectonia grandis $(0.125 \%)$. The implication for the environment was that the Prosopis africana was the most likely among the branch samples to produce more oxides of nitrogen with their concomitant side effects to the environment in terms of health hazards and the production of photochemical smog, whilst Albizie ferruginea was the most likely to do the same among the trunks. The nitrogen content of the branches correlated negatively $\left(\mathrm{R}^{2}=0.001\right)$ with the GHVe, while that of the trunk samples correlated positively $\left(\mathrm{R}^{2}=0.115\right)$ (Figure 7 and Figure 8).

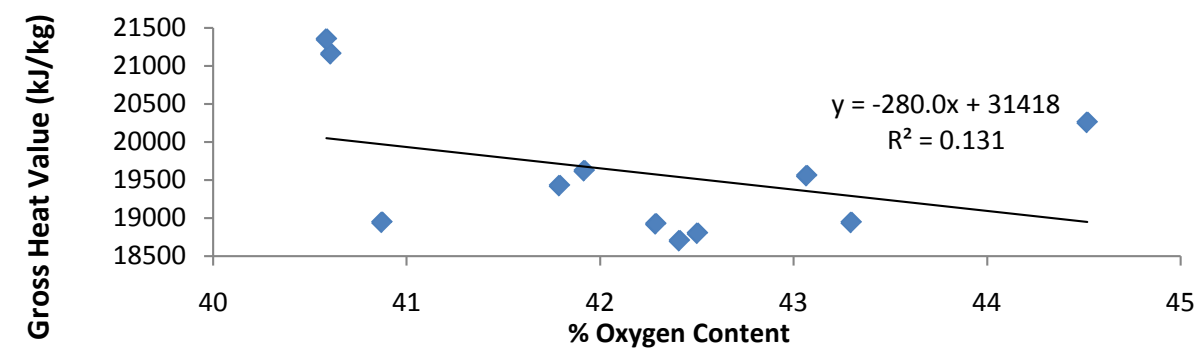

Figure 5. A Plot of experimental gross heat value versus \% oxygen content of selected trees (branches).

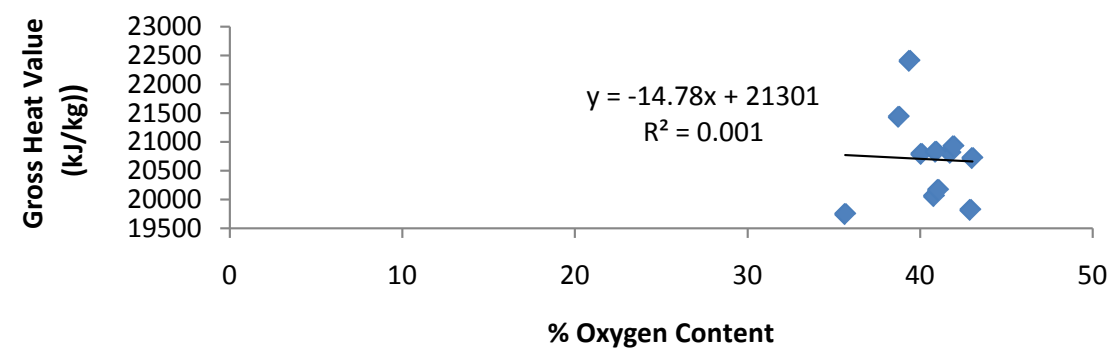

Figure 6. A Plot of experimental gross heat value versus \% oxygen content of selected trees (trunks). 

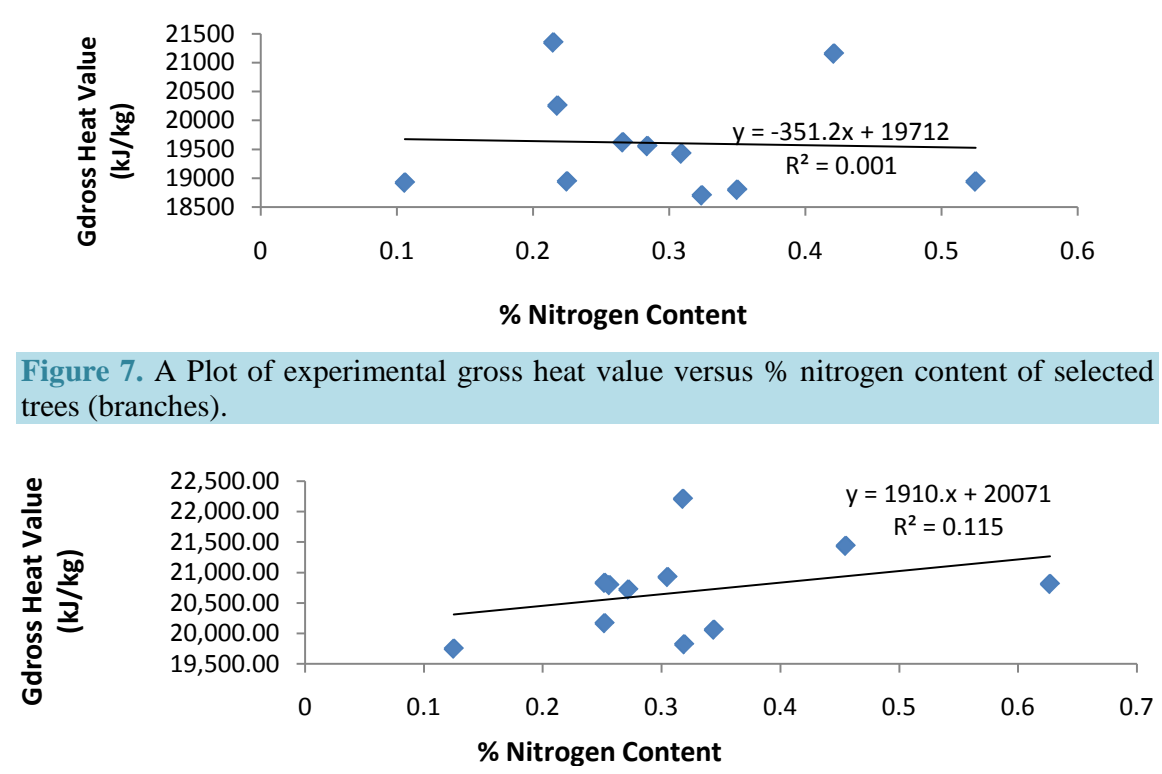

Figure 8. A Plot of experimental gross heat value versus \% nitrogen content of selected trees (trunks).

The $0.627 \% \mathrm{~N}$ content of the trunk Albizie ferruginea is significant since it was higher than the limit set by the German national standard for fuel pellet, that is, Nitrogen $\leq 0.3 \%$, as well as that set by the Austrian national standard for pellet and briquettes: Nitrogen $\leq 0.6 \%$ [12].

\subsection{Sulphur Content}

Apart from the branch of Prosopis africana (0.055\%), there was no trace of sulphur in the branches and trunks of all the species examined (Table 1 and Table 2). The level of concentration of sulphur in this tree was however well below the standard set by both the Austrian and German national standards for fuel pellets and briquettes (sulphur content $\leq 0.08 \%$ ). It could be deduced therefore, that the negative environmental impact with respect to harmful emissions of oxides of sulphur was practically non-existent thus making the woods in the aforementioned geographical location environmentally friendly.

\subsection{Gross Heat Value/Ash Content}

The results of the determination of the ash content for the samples in question showed that the branches ranged from Brachistigia eurycoma (4.66\%) to Albizia ferruginea (0.98). For the trunks, the values ranged from Afzelia africana (7.69\%) to Albizia ferruginea (0.1\%). Data analysis showed that a negative correlation, with $\mathrm{R}^{2}=0.076$ existed between the ash content (branches) and the calorific value (Figure 9), while the ash content of the trunks correlated positively (Figure 10) with $\mathrm{R}^{2}=0.058$ due to the outlier (Prosopis africana, 5.88). Otherwise, a negative correlation as expected would have been the outcome with $\mathrm{R}^{2}=0.01$.

Ash deposit on heat transfer surfaces in boilers and internal surfaces in gasifiers quicken the rate at which corrosion occurs on hot heat exchanging equipments and also reduces its efficiency [12]. The ash content of all the wood samples studied (Table 1 and Table 2), except for Afzelia africana, was less than $6 \%$. When the ash content is above $6 \%$, the wood fuel may be considered inadequate [12]. Albizia ferruginea had the lowest ash content for both trunks and branches. This quality will make it quite suitable as a wood fuel for combustion systems. Their low ash contents no doubt impacted on their relatively high calorific values, 19,557.01 kJ/kg and $20,810.72 \mathrm{~kJ} / \mathrm{kg}$. The branch of Afzelia africana (2.5\%) was preferable to the trunk (7.69\%) for fuel so as to reduce problems arising from clogged ash removal caused by slagging ash to severe operating problems in fluidized bed systems [6]. Since it has been noted that a biomass with high mineral contents will have a negative impact on the heat content by lowering it [6] [13] [17], the anomalous case of Tectonia grandis which had a relatively high C content (47.245\%), but surprisingly had the lowest GHV (19,747.74 kJ/kg) can be explained. This can be attributed to the relatively high ash content of $5.05 \%$ for its trunk and $2.94 \%$ for its branch. Nevertheless, 


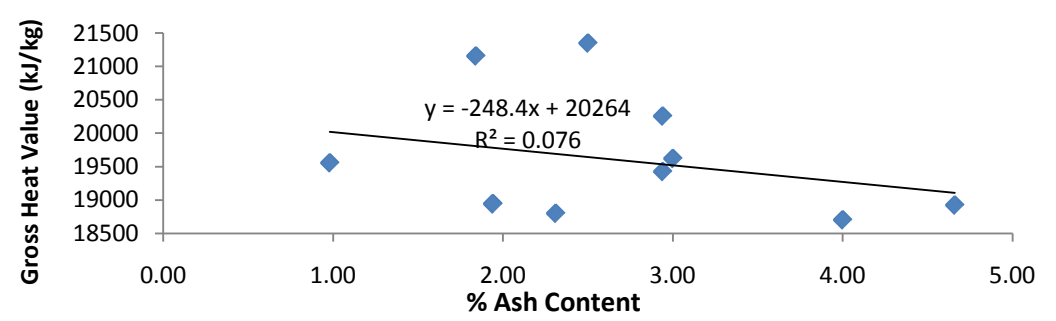

Figure 9. A Plot of experimental gross heat value versus \% ash content ratio of selected trees (branches).

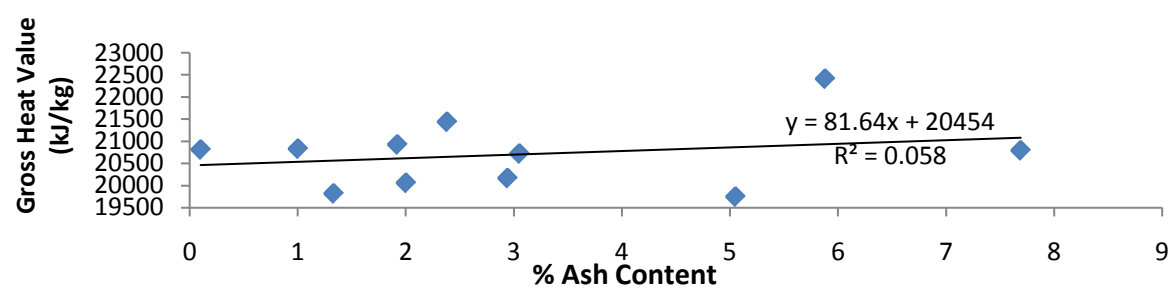

Figure 10. A Plot of experimental gross heat value versus \% ash content ratio of selected trees (trunks).

it should be noted that statistical analysis (T-Test) with respect to the ash content of the tree samples showed that there was no significant difference between main branches when compared with their corresponding main trunks $(0.606 \geq 0.05)$.

\subsection{Density}

The density of biomass plays an important role in the determination of its value as fuel in that the denser the wood, the more heat per unit volume it is likely to contain and the longer period of time the burning can be sustained [12]. The bulk densities of our branch samples (Table 1) ranged from the highest in Erythrophleum suaveolens $\left(0.284 \mathrm{~g} / \mathrm{cm}^{3}\right)$ to the lowest in Prosopis africana $\left(0.079 \mathrm{~g} / \mathrm{cm}^{3}\right)$. For the trunk samples (Table 2), the range was from Prosopis africana $\left(0.261 \mathrm{~g} / \mathrm{cm}^{3}\right)$ to the lowest in Morinda lucida $\left(0.111 \mathrm{~g} / \mathrm{cm}^{3}\right)$.

It is important to note that the tree trunk sample with the highest bulk density had the highest calorific value as well (Table 2), that is, Prosopis africana $\left(0.261 \mathrm{~g} / \mathrm{cm}^{3}, 22,408.68 \mathrm{~kJ} / \mathrm{Kg}\right)$. However, a negative correlation $\left(\mathrm{R}^{2}=0.025\right)$ between the bulk density and the calorific value of the branches was noted. In the case of trunks, the correlation was positive $\left(\mathrm{R}^{2}=0.204\right)$. Hence, the effect of correlation between the calorific value and the density was more in the trunks than branches $(0.204>0.025)$ (Figure 11 and Figure 12).

The trend did not follow precisely so in the case of branches where Afzelia africana $\left(0.238 \mathrm{~g} / \mathrm{cm}^{3}, 21,350.35\right.$ $\mathrm{kJ} / \mathrm{Kg}$ ) which had the highest calorific value was however second highest in density (Table 1). Erythrophleum suaveolens $\left(0.284 \mathrm{~g} / \mathrm{cm}^{3}, 18,945.27 \mathrm{~kJ} / \mathrm{kg}\right)$ did not necessarily have the highest calorific value. This implied that density alone, even though could be a contributing variable may not be a major factor in the energy content of a timber species.

\subsection{Carbon Dioxide $\left(\mathrm{CO}_{2}\right)$ Emission Factor}

Among the branches, the highest $\mathrm{CO}_{2}$ emission factor was observed in Prosopis africana (111.310), while the lowest value was noted in Nauclea diderrichii (104.703). With respect to the trunks, the highest value was observed in Morinda lucida (110.439), while the lowest was in Tectonia grandis (99.558). As has been noted, carbon dioxide emissions from the burning of biomass such as wood are considered as neutral, therefore not reckoned in the Green House Gas (GHG) inventory [18]. Nevertheless, the results as calculated by the software (Eager 300) attached to the organic elemental analyser are presented (Table 1 and Table 2).

\subsection{Rating}

An overall rating of the eleven tropical timbers studied was done, taking into consideration other variables and 

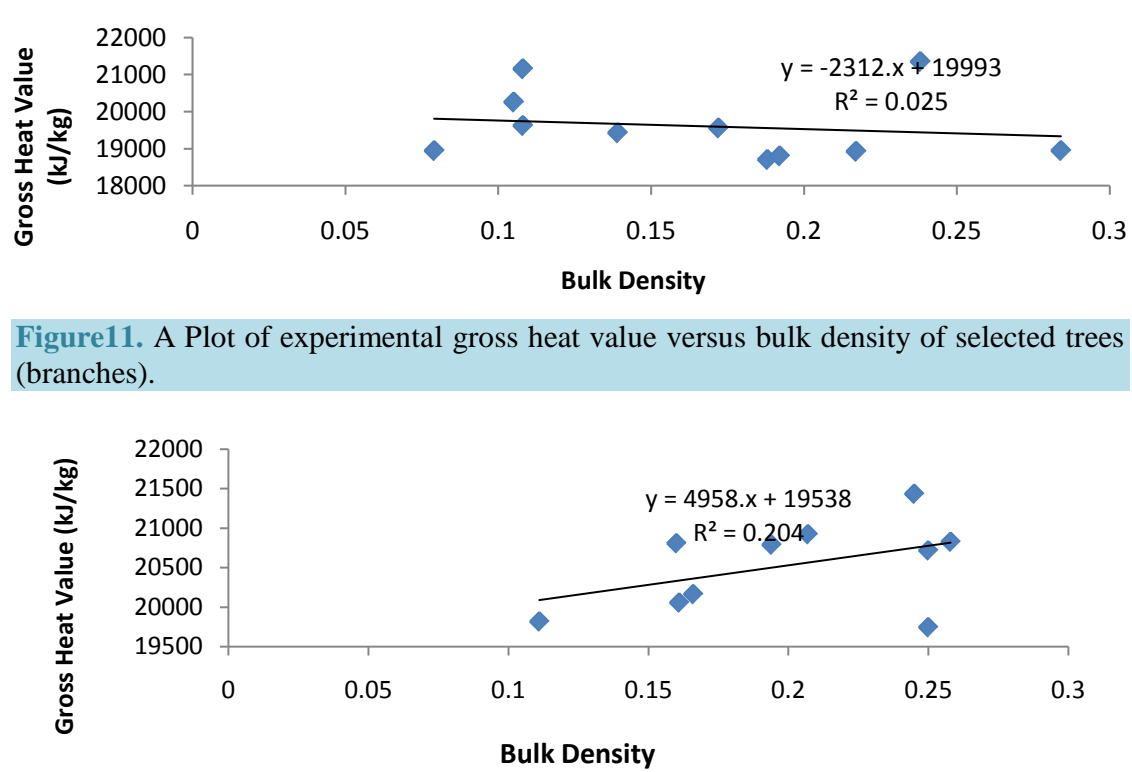

Figure 12. A Plot of experimental gross heat value versus bulk density of selected trees (trunks).

not just the calorific value as the sole criterion for determining the best choice of species for fuel wood production (Table 3 and Table 4). The importance of this approach has been noted [19].

The order from the most desirable to the least, with respect to the branches (Table 3) was:

Afzelia africana $>$ Erythophleum suaveolens $>$ Nauclea diderichii $>$ Dialium guinensis $>$ Pentaclethra macrophylla $>$ Albizie ferruginea $>$ Morinda lucida $>$ Tectonia grandis $>$ Brachistigia eurycoma $>$ Lophira lanceolata $>$ Prosopis africana.

With respect to the trunks (Table 3, Table 4), the order of rating in decreasing order of desirability was:

Erythophleum suaveolens $>$ Nauclea diderichii $>$ Tectonia grandis $>$ Prosopis africana $>$ Afzelia africana $>$ Dialium guinensis $>$ Lophira lanceolata $>$ Brachistigia eurycoma $>$ Albizie ferruginea $>$ Pentaclethra macrophylla $>$ Morinda lucida.

\section{Conclusion}

This study investigated the calorific values of 11 tropical timbers in correlation with their chemical composition. From the experimental results, it may be concluded that in most cases, the trunks had higher calorific values than the branches mainly due to their relatively higher carbon content. The impact of the carbon concentration on the trunks $\left(\mathrm{R}^{2}\right.$ factor $\left.=0.483\right)$ was more than that of the branches $\left(\mathrm{R}^{2}=0.178\right)$. The branch of Afzelia africana had a higher calorific value than the trunk $(21,350.350 \mathrm{~kJ} / \mathrm{kg}>20,792.11 \mathrm{~kJ} / \mathrm{kg})$ probably due to differences in their ash contents and the concentration of carbon. The trunk of Albizie ferruginea had a \% $\mathrm{N}$ concentration $(0.627 \%)$ which was above the standards and should not be considered for wood fuel. The absence of sulphur in almost all the samples was indicative of the fact that the woods in the aforementioned geographical location were environmentally friendly biomass fuels. This research has thus highlighted the importance of considering such factors as environmental impacts, health issues and tree parts in the selection of a species for use as wood fuel. Even though all the woods studied in this work may be considered good sources for firewood and charcoal production based on their calorific value alone, the pride of place should be given to branch of Afzelia africana (21,350.35 kJ/kg); the branch and trunk of Nauclea diderrichii (21,157.30 kJ/kg, 21,436.42 kJ/kg); the branch of Tectonia grandis (20,257.13 kJ/kg); the trunk of Prosopis africana $(22,408 \mathrm{~kJ} / \mathrm{kg})$, provided they are not being used for hot water boilers; and the trunk of Brachistigia eurychoma $(20,924.7 \mathrm{~kJ} / \mathrm{kg})$ in the light of the aforementioned variables.

\section{Acknowledgements}

The authors are very grateful to Dr. Liliana Krotz and the CE Elantech Group at Oberlin, New Jersey, Professor 
Table 3. Rating of fuel properties of eleven tropical timbers (branches).

\begin{tabular}{|c|c|c|c|c|c|c|c|c|c|c|}
\hline Botanic Name of Tree & N\% & $\mathrm{C} \%$ & H\% & $\mathrm{S} \%$ & $\mathbf{0} \%$ & GHVe (kJ/kg) & $\begin{array}{c}\% \text { Ash } \\
\text { Content }\end{array}$ & B. D. $\mathrm{g} / \mathrm{cm}^{3}$ & $\mathrm{CO}_{2}$ E.F. & Total 1 \\
\hline Lophira lanceolata & 8 & 4 & 8 & 1 & 7 & 11 & 10 & 5 & 7 & 61 \\
\hline Erythophleum suaveolens & 4 & 2 & 2 & 1 & 3 & 7 & 3 & 1 & 2 & 25 \\
\hline Pentaclethra macrophylla & 9 & 5 & 3 & 1 & 8 & 10 & 5 & 4 & 6 & 51 \\
\hline Prosopis africana & 11 & 11 & 11 & 2 & 10 & 8 & 4 & 11 & 11 & 79 \\
\hline Tectonia grandis & 3 & 6 & 5 & 1 & 11 & 3 & 7 & 10 & 10 & 56 \\
\hline Nauclea diderichii & 10 & 3 & 1 & 1 & 2 & 2 & 2 & 8 & 1 & 30 \\
\hline Brachistigia eurycoma & 1 & 8 & 10 & 1 & 6 & 9 & 11 & 3 & 8 & 57 \\
\hline Afzelia africana & 2 & 1 & 7 & 1 & 1 & 1 & 6 & 2 & 3 & 24 \\
\hline Dialium guinensis & 7 & 9 & 4 & 1 & 4 & 6 & 8 & 7 & 4 & 50 \\
\hline Albizie ferruginea & 6 & 7 & 9 & 1 & 9 & 5 & 1 & 6 & 9 & 53 \\
\hline Morinda lucida & 5 & 10 & 6 & 1 & 5 & 4 & 9 & 9 & 5 & 54 \\
\hline
\end{tabular}

Table 4. Rating of fuel properties eleven tropical timbers (trunks).

\begin{tabular}{|c|c|c|c|c|c|c|c|c|c|c|}
\hline Botanic Name of Tree & $\mathbf{N} \%$ & $\mathrm{C} \%$ & $\mathbf{H} \%$ & $\mathrm{~S} \%$ & O\% & $\begin{array}{l}\text { GHVe } \\
(\mathbf{k J} / \mathbf{k g})\end{array}$ & $\begin{array}{l}\% \text { Ash } \\
\text { content }\end{array}$ & B. D. $\mathbf{g} / \mathrm{cm}^{3}$ & $\begin{array}{l}\mathrm{CO}_{2} \\
\text { E.F. }\end{array}$ & Total 2 \\
\hline Lophira lanceolata & 5 & 5 & 7 & 1 & 7 & 7 & 8 & 3 & 10 & 53 \\
\hline Erythophleum suaveolens & 2 & 3 & 5 & 1 & 6 & 4 & 2 & 2 & 4 & 29 \\
\hline $\begin{array}{l}\text { Pentaclethra } \\
\text { macrophylla }\end{array}$ & 9 & 9 & 8 & 1 & 5 & 9 & 5 & 9 & 8 & 63 \\
\hline Prosopis africana & 7 & 1 & 10 & 1 & 3 & 1 & 10 & 1 & 6 & 40 \\
\hline Tectonia grandis & 1 & 4 & 3 & 1 & 1 & 11 & 9 & 4 & 1 & 35 \\
\hline Nauclea diderichii & 10 & 2 & 1 & 1 & 2 & 2 & 6 & 5 & 2 & 31 \\
\hline Brachistigia eurycoma & 6 & 7 & 9 & 1 & 9 & 3 & 4 & 6 & 9 & 54 \\
\hline Afzelia africana & 4 & 6 & 6 & 1 & 4 & 6 & 11 & 7 & 3 & 48 \\
\hline Dialium guinensis & 3 & 8 & 4 & 1 & 7 & 8 & 7 & 8 & 5 & 51 \\
\hline Albizie ferruginea & 11 & 10 & 2 & 1 & 8 & 5 & 1 & 10 & 7 & 55 \\
\hline Morinda lucida & 8 & 11 & 11 & 1 & 10 & 10 & 3 & 11 & 11 & 76 \\
\hline
\end{tabular}

Note: Numerical values $(1$ - 11) were assigned to the various samples in order of their desirability for each variable. Hence, 1 = best/most desirable and $11=$ worst/least desirable.

Armando McDonald of the University of Idaho and Dr. Onyebuchi Nwadiogbu of the Caritas University, Enugu for providing the laboratory support for this work. They also appreciate the assistance of Dr. Goodness Orluwene of the University of Port Harcourt for providing the statistical software for this study, as well as the massive input of Mr. Linus Eko of the Forestry Department of Enugu state, Nigeria.

\section{References}

[1] Khider, T.O. and Elsaki, T.O. (2012) Heat Value of Four Hardwood Species from Sudan. Journal of Forest Products \& Industries, 1, 5-9.

[2] Ramachandra, T. and Kamakshi, G. (2005) Bioresource Potential of Karnataka. Technical Report No: 109: The Ministry of Environment and Forests, Government of India, Centre for Ecological Sciences, Indian Institute of Science, Bangalore. http://wgbis.ces.iisc.ernet.in/energy/paper/TR109/tr109_mainframe.htm

[3] Keita, J.D., (1987). Wood or Charcoal—Which Is Better? Unasylva: An International Journal of Forestry and Forest Industries. Vol.39. FAO_Food and Agriculture Organization of the United Nations, Rome. Richard Pardo (Ed.). http://www.fao.org/docrep/s4550e/s4550e09.htm 
[4] Meathead, G. (2013) The Science of Charcoal: How Charcoal Is Made and How Charcoal Works. www.biofuelregion.se/UserFiles/file/Forest Refine/1_2_IS_2013-01-31_Basic_chemical_composition.pdf

[5] Tancredi, N., Cuna, A. and Yoshida, M. (2010) Wood Pyrolysis: Influence of Pyrolysis Temperature and Heating Rate on Charcoal Properties and Pyrolysis Process. Chemical Physics Research Journal, 3, 104-114.

[6] Moka, V.K. (2012) Estimation of Calorific Value of Biomass from Its Elementary Components by Regression Analysis. BTech Thesis. http://mechdocs-thesis.blogspot.com/2013/01/estimation-of-calorific-value-of.html

[7] Thermo Fisher Scientific Inc. (2008) Flash 2000 Series CHN/CHNS/ Oxygen Automatic Elemental Analyser. https://www.thermoscientific.com/content/dam/tfs/ATG/CMD/CMD\%20Documents/BR-11012-FLASH-2000-SeriesCHN-CHNS-Oxygen-Automatic-Elemental-Analyzer.pdf

[8] Parr Instrument Company (2008) Oxygen Bomb Calorimeter (1341). Illinois, p. 16.

[9] Dara, S.S. (1991) Experiments and Calculations in Engineering Chemistry. S. Chand and Co. Ltd., New Delhi, 185191.

[10] Aloko, D.F. and Adebayo, G.A. (2007) Production and Characterization of Activated Carbon from Agricultural Wastes (Rice Husk and Corn Cob). Journal of Engineering and Applied Sciences, 2, 440-444.

[11] Azubuike, C.P and Okhamafe, A.O. (2012) Physicochemical, Spectroscopic and Thermal Properties of Microcrystalline Cellulose Derived from Corn Cobs. International Journal of Recycling Organic Waste in Agriculture, 1, 9.

[12] Mitchual, S.J., Frimpong-Mensah, K. and Darkwa, N.A. (2014) Evaluation of Fuel Properties of Six Tropical Hardwood Timber Species for Briquettes. Journal of Sustainable Bioenergy Systems, 4, 1-9. http://dx.doi.org/10.4236/jsbs.2014.41001

[13] Demirbas, A. (2008) Biodiesel: A Realistic Fuel Alternative for Diesel Engines. Springer, London, 21-22.

[14] White, R.H. (1986) Effect of Lignin Content and Extractives on the Higher Heating Value of Wood. Wood and Fiber Science, 19, 446-452.

[15] Raisanen, T. and Athanassiadis, D. (2013) Basic Chemical Composition of the Biomass Components of Pine, Spruce and Birch. http://amazingribs.com/tips_and_technique/zen_of_charcoal.html

[16] Lhate, I. (2011) Chemical Composition and Machinability of Selected Wood Species from Mozambique. Doctoral Thesis, Faculty of Forestry, Department of Forest Products, Swedish University of Agricultural Sciences, Uppsala. Acta Universitatis Agriculturae Sueciae, 2011:48.

[17] Susott, R.A., DeGroot, W.F. and Shafizadeh, F. (1975) Heat Content of Natural Fuels. Journal of Fire and Flammability, 6, 311-325.

[18] Tarnawski, W. (2004) Emission Factors for Combustion of Biomass Fuels in the Pulp and Paper Mills. Journal of Fibres \& Textiles in Eastern in Eastern Europe, 12, 91-95.

[19] Nirmal-Kumar, J.I., Kanti, P., Kumar, R.N. and Kumar-Bhoi, R. (2009) An Assessment of Indian Fuelwood with Regards to Properties and Environmental Impact. Asian Journal on Energy and Environment, 10, 99-107. 